ISSN: 2146-0574, eISSN: 2536-4618

Tarım Ekonomisi / Agricultural Economy

DOI: 10.21597/jist.763595

Araştırma Makalesi / Research Article

Geliş tarihi / Received: 03-07-2020

Kabul tarihi / Accepted: 05-10-2020

Tarım Sektörü Hisse Senetlerinden Oluşan Portföy Riskinin Monte Carlo Simülasyonu ile Hesaplanması Duran GÜLER ${ }^{1 *}$

ÖZET: Sermaye piyasasında fiyat dalgalanmalarının neden olduğu belirsizlik yatırımcılar açısından risk oluşturmaktadır. Bu riski yönetebilecek çeşitli yöntemler bulunmaktadır. Bu çalışmanın amacı riske maruz değer yöntemlerinden biri olan Monte Carlo simülasyonu ile tarım sektörü hisse senetlerinden oluşan bir portföyün risk düzeyinin ölçülmesidir. Çalışmada, BIST’te işlem gören IZTAR, TACTR ve YAPRK hisse senetlerine ait kapanış fiyatları kullanılmıştır. Eşit ağırlıklı olarak oluşturulmuş varsayımsal portföyün riske maruz değer oranları 10 günlük elde tutma süresinde $\% 95$ ve \% 99 güven aralıklarında sırasıyla \% 24.36 ve \% 34.61 olarak saptanmıştır. Literatürdeki çalışmalarla karşılaştırıldığında tarım sektörü hisse senetlerinden oluşan bir portföye ilişkin risk düzeyinin döviz, bankacılık hisse senetleri ve devlet iç borçlanma senetlerinden oluşan portföylerin risk düzeyinden daha fazla olduğu belirlenmiştir. $\mathrm{Bu}$ durumun nedenlerini yatırımcı kararları çerçevesinde inceleyen araştırmaların yapılması önerilmektedir.

Anahtar Kelimeler: Finansal risk yönetimi, portföy riski, riske maruz değer, Monte Carlo simülasyonu

\title{
Calculation of Risk of Portfolio Consisting of Agricultural Sector Stock via Monte Carlo Simulation
}

ABSTRACT: The uncertainty caused by price volatility in the capital market poses risk for investors. There are several methods to manage this risk. The aim of this study is to measure the risk of a portfolio consisting of agricultural sector stock via Monte Carlo simulation, which is one of the value at risk methods. The daily closing stock prices of IZTAR, TACTR, and YAPRK that are traded in BIST were used in the study. The value at risk ratios of the equally weighted hypothetical portfolio were determined as $24.36 \%$ and $34.61 \%$ at $95 \%$ and $99 \%$ confidence levels on a ten-day holding period, respectively. Compared with previous studies, it has been determined that the risk of a portfolio consisting of agricultural sector stock is higher than the risk of portfolios consisting of foreign exchange, banking stock and government debt securities. It is recommended to conduct searches that examine the causes of this situation in the framework of investor decisions.

Keywords: Financial risk management, portfolio risk, value at risk, Monte Carlo simulation

${ }^{1}$ Duran GÜLER (Orcid ID: 0000-0001-8555-0877), Ege Üniversitesi, Ziraat Fakültesi, Tarım Ekonomisi Bölümü, İzmir, Türkiye

*Sorumlu Yazar/Corresponding Author: Duran GÜLER, e-mail: duran.guler@ege.edu.tr 


\section{GÍRIȘ}

Risk, en genel tanımıyla varlık, sermaye ya da kazanç değerinde olasılığa dayalı ölçülebilir beklenmeyen kayıplar olarak ifade edilebilir. İşletmeler çeşitli risklerle karşı karşıya olmakla birlikte bu riskler temelde işletme ve finansal risklerdir (Jorion, 2007). Bununla birlikte riskler finansal sistemin bütününü etkileyebilen sistematik riskler ve etkisi daha çok firmayı ve sektörü etkileyebilebilecek yapıya sahip sistematik olmayan riskler şeklinde sınıflandırılmaktadır (Yıldırım ve Kantar, 2018). Gelecekte herhangi bir kayba ya da tehlikeye neden olabilecek durumların ortaya çıkması ya da finansal açıdan değerlendirildiğinde yatırımcının bir varlıktan beklediği getirinin gerçekleşen getirisinden sapma olasılığı olarak tanımlanan risk kavramı yatırımcılar için önemli bir unsurdur. Çünkü yatırımcıların yatırımlarından bekledikleri kazancın beklentilerinin altında kalması ya da üzerine çıkması durumu riski oluşturmaktadır ve bu risk finansal piyasalarda belirli zaman aralıklarında gerçekleşen fiyat dalgalanmalarından kaynaklanmaktadır (Korkmaz ve Pekkaya, 2012; Şener, 2018). Belirsizliğe neden olan bu dalgalanmaların olumsuz etkisinden korunmak isteyen yatırımcılar için belirsizliğin ölçülebilen kısmı olarak ifade edilen riskin yönetilmesi gerekmektedir (Usta, 2008; Usta ve Demireli, 2010).

Risk yönetimi için çeşitli yöntemler bulunmaktadır. Genel olarak hisse senetleri veya diğer yatırım araçlarından oluşturulan portföylerde geleneksel yöntemlerle dağıtım yapılabilmektedir. Bunun yanı sıra riski azaltarak getiriyi artırmayı amaçlayan ve bunu sağlayabilmek için portföyde yer alan yatırım araçları arasındaki ilişkiyi dikkate alan modern portföy yöntemleri de kullanılmaktadır. Yatırımcının portföy bileşimi kararında riske karşı duyduğu hassasiyet etkili olacaktır (Avşarlıgil, 2020). Risk yönetim yöntemlerinden olan riske maruz değer (RMD-VaR:Value at Risk) anlaş1lırlığı ve uygulama kolaylığının yanı sıra finansal risk yönetiminde kullanılan ilk yöntemlerden biri olarak kabul edilmektedir (Zhu ve ark., 2020). JP Morgan Grubu tarafından Risk Ölçütleri risk yönetim sisteminin genişletilmesiyle türetilmiş olan riske maruz değer, belirli bir güven aralığında ve belirli bir sürede elde tutulacak finansal varlıkların, belirli bir olasılıkla karşılaşabileceği maksimum değer kaybını ifade etmektedir (Akan ve ark., 2003; Avşarlıgil ve ark., 2015; Kavrar ve Yılmaz, 2019). Birçok uluslararası finansal kuruluş tarafından benimsenmiş olan riske maruz değer yöntemleri finans ve sigorta alanında en sık kullanılan risk ölçüm yöntemleridir (Taş ve İltüzer, 2008, Embrechts ve Puccetti, 2010).

Literatürde riske maruz değer yöntemleri kullanılarak yapılan çalışmalar mevcuttur ve bunların birçoğu BIST’te (Borsa İstanbul) işlem gören hisselerden oluşan portföy riskleriyle ilişkilidir. Avşarlıgil ve ark. (2015) spor kulubü hisse senetlerinden oluşan iki farklı sanal portföyü incelemişlerdir. Eser (2010) farklı sektörlerden beş hissenin oluşturduğu portföy riskini iki farklı RMD yöntemiyle incelemiş ve sonuçları karşılaştırmıştır. Koldere Akın ve Akduğan (2012) çalışmalarında Türkiye'de faaliyet gösteren gelir amaçlı kamu borçlanma araçları emeklilik yatırım fonlarından oluşturulmuş portföylerin riskini ölçmüşler ve bu fonların düşük fonlar grubuna girdiğini saptamışlardır. Bayram ve Kısava (2019) BIST 30 endeksi içerisinde yer alan beş şirketin hisse senetlerinden oluşan bir portföyün risk düzeyini Varyans-Kovaryans, Tarihsel simülasyon ve Monte Carlo simülasyonu yöntemleri ile incelemişlerdir. Taş ve İltüzer (2008) IMKB30 endeksi ve Devlet İç Borçlanma Senetleri portföylerinin riske maruz değerlerini Monte Carlo simülasyon yöntemi ile hesaplamışlar ve İMKB30 endeksinin tahvil ve bonoya kıyasla daha riskli bir yatırım aracı olduğunu saptamışlardır. Uçkun ve Kandemir (2008) bilişim ve bankacılık alanında faaliyet gösteren şirketlere ait hisse senetlerinden oluşturulmuş iki portföyün riske maruz değer sonuçlarını Varyans-Kovaryans yöntemi ile belirlemişlerdir. Yıldırım ve Çolakyan (2014) Varyans-Kovaryans yöntemi, Tarihsel simülasyon yöntemi, Monte Carlo simülasyon yöntemi ve Üssel Ağırlıklandırılmış Hareketli Ortalama 
(ÜAHO) yöntemini döviz, BIST 100 ve BIST 30 Endekslerine uygulayarak sonuçlarını karşılaştırmışlar ve yapılan hesaplamalar sonucunda en az zararın Monte Carlo simülasyon yöntemiyle elde edildiğini saptamışlardır. Kavrar ve Yılmaz (2019) Tarihsel simülasyon yöntemini kullanarak BIST 100 Endeksinde yer alan Türk Telekomünikasyon A.Ş. (TTKOM) ve Ford Otosan (FROTO) A.Ş.'ye ait hisse senetleri, euro ve altından oluşturulmuş varsayımsal bir portföy için RMD tutarlarını hesaplamışlardır. Ural (2009) ise İMKB100 (Türkiye), FTSE100 (İngiltere), NIKKEI225 (Japonya) ve CAC40 (Fransa) borsa endekslerine ilişkin riske maruz değer ve beklenen kayıp analizleri yapmıştır. Küçük (2010) kredi riski yönetiminde farklı sanal portföylerde, Demireli ve Taner (2009) ise Euro, Altın ve ABD Doları'ndan oluşan bir portföyde riske maruz değer ölçümü için Monte Carlo simülasyon yönteminden yararlanmıştır.

Literatürde daha önce tarım sektörü hisse senetlerinden oluşan bir portföye ilişkin herhangi bir çalışmaya rastlanmamıştır. Tarımın doğal koşullara bağllı̆̆ı, elde edilen ürünlerin depolanabilme süresinin sınırlllı̆̆ı ve tarımsal ürünlerde arz esnekliğinin düşük olması gibi özellikler tarım sektörünü diğer sektörlerden ayırmaktadır. Bu durumun tarım sektöründe faaliyet gösteren halka açı şirketlere ait hisse senetlerinin risk düzeylerine de etki edebileceği göz önüne alındığında bu hisselerden oluşan portföy riskinin belirlenmesi yatırımcılar açısından önem arz etmektedir.

$\mathrm{Bu}$ çalışmada riske maruz değer yöntemlerinden biri olan Monte Carlo simülasyonu ile tarım sektöründe faaliyet gösteren halka açık şirketlerin hisse senetlerinden oluşan portföy riskinin ölçülmesi amaçlanmıştır. Tarım sektörü kategorisinde payları Borsa İstanbul Pay Piyasası'nda işlem gören sadece üç şirket bulunmaktadır. Bu nedenle incelenen portföy bu şirketlere ait IZTAR, TACTR ve YAPRK hisse senetlerinden oluşmaktadır (Anonim, 2020).

\section{MATERYAL VE YÖNTEM}

Çalışmada BIST'te işlem gören IZTAR, TACTR ve YAPRK hisse senetlerine ilişkin 02.01.2018 - 30.12.2019 tarihleri arasındaki 499 günlük kapanış fiyatları kullanılmışıı. Verilerin analizi sürecinde betimleyici istatistiklerin hesaplanmasinda SPSS 20 paket program1, simülasyon sürecinde ise Microsoft Office Excel 2010 kullanılmıştır.

Riske maruz değer yöntemleri olarak benimsenen temel yaklaşımlar Varyans-Kovaryans yöntemi, Tarihsel simülasyon yöntemi ve Monte Carlo simülasyon yöntemidir (Taş ve İltüzer, 2008). $\mathrm{Bu}$ yöntemlerden Varyans-Kovaryans yöntemi parametrik iken; Tarihsel simülasyon ve Monte Carlo simülasyon yöntemleri parametrik olmayan yöntemlerdir (Bayram ve Kısava, 2019). Parametrik yöntemler varlık getirilerinin normal dağıldığı hipotezi altında tanımlanan bir güven düzeyine bağlıdırlar. Parametrik olmayan yöntemler ise varlık getirilerinin dağılımıyla ilgili olarak herhangi bir hipoteze dayanmamaktadırlar. Riske maruz değer yöntemleri arasında Monte Carlo simülasyon yönteminin Türkiye piyasalarında en geçerli yöntem olduğu belirlenmiştir (Demireli ve Taner, 2009). Ayrıca getiri serileri normal dağılıma sahip olan verilerin analizinde Varyans-Kovaryans yönteminin daha iyi sonuçlar verdiği ve normal dağılıma uymayan seriler için Monte Carlo simülasyon yöntemi kullanılmasının daha uygun olduğu belirtilmektedir (Koldere Akın ve Akduğan, 2012). Simülasyon yönteminin bu esnekliği, riske maruz değer hesaplamasında en güçlü yaklaşım olmasını sağlamaktadır (Jorion, 2007).

Belirlenen portföyde meydana gelebilecek en yüksek zararı geleceğe yönelik ve parasal değer olarak ifade etmek amacıyla kullanılan RMD yöntemlerinde portföyü elde tutma süresi, örnekleme periyodu, güven aralığı ve risk faktörleri arasındaki korelasyon belirlenmelidir (Koldere Akın ve Akduğan, 2012). Bu çalışmada portföy riskini belirlemek amacıyla Monte Carlo simülasyon yönteminden yararlanılmıştır. Monte Carlo simülasyon yönteminde fiyatlardaki olası değişimleri 
yeterli düzeyde temsil edebileceği düşünülen bir istatistiki dağılım seçilerek gerçek olmayan fiyatlar üretilip rassal senaryolar meydana getirilmektedir. Maruz kalınan piyasa risklerinin doğru bir şekilde ölçülebilmesi için riske maruz değerin belirlenmesinde kullanılan geçmiş gözlem döneminin bir yıldan az (252 iş günü) olmaması gerekmektedir (Aktan, 2007).

Portföyde bir risk faktörünün bulunduğu durumlarda kullanılan stokastik model Geometrik Brownian Motion (GBM) modelidir (Jorion, 2007; Taş ve İltüzer, 2008). Standart normal dağılıma sahip ve birbirinden bağımsız değişimlerin olduğu varsayılan bu modelin (1) denklemi aşağıda verilmiştir.

$$
\begin{array}{ll}
\Delta S_{t}=S_{t-1}(\mu \Delta t+\sigma \psi \sqrt{\Delta t}) \\
\Delta S_{t} \quad: \text { Fiyattaki değişim } \\
\mu \quad: \text { Ortalama getiri } \\
\Delta t \quad: \text { Zaman aralığı } \\
\sigma \quad: \text { Standart sapma } \\
\psi \quad: \text { Standart normal dağılımdan türetilmiş rassal sayı }
\end{array}
$$

Çoklu risk faktörlerinden oluşan portföyde GBM'nin kullanılabilmesi için faktörler arasındaki korelasyon sıfır olmalıdır. Uygulamada bu koşul sağlanamayacağı için faktörler arasındaki korelasyonu da dikkate alan model oluşturmak için $\psi_{i}$ değişkenleri birbirinden bağımsız $\eta_{i}$ değişkenleri ile tanımlanmaktadır. Buna göre iki risk faktörlü bir portföyde (2) denkleminden yararlanılmaktadır.

$$
\begin{aligned}
& \psi_{1}=\eta_{1} \\
& \psi_{2}=a \eta_{1}+b \eta_{2}
\end{aligned}
$$

Denklemde yer alan $\psi_{i}$ 'leri belirleyebilmek için $a$ ve $b$ parametlerinin hesaplanmasında Cholesky faktörizasyonu kullanılmaktadır. Cholesky faktörizasyon pozitif definit bir matrisi (3) alt üçgensel matris ve bunun transpozesinin çarpımı olarak ifade edilmesini sağlamaktadır.

$$
\begin{aligned}
& R=T T^{\prime} \\
& R: \text { Pozitif definit matris } \\
& T: \text { Cholesky decompoze matris } \\
& T^{\prime}: \text { Cholesky matrisinin transpozesi }
\end{aligned}
$$

T matrisi elde edildikten sonra $\psi_{i}$ 'ler (4) numaralı denklemde gösterildiği şekilde hesaplanmaktadır.

$$
\left[\begin{array}{c}
\psi_{1} \\
\psi_{2} \\
\vdots \\
\psi_{n}
\end{array}\right]=\left[\begin{array}{ccccc}
a_{11} & 0 & 0 & \cdots & 0 \\
a_{21} & a_{22} & 0 & \cdots & 0 \\
\vdots & \vdots & \vdots & \vdots & \vdots \\
a_{n 1} & a_{n 2} & \cdots & \cdots & a_{m n}
\end{array}\right]\left[\begin{array}{c}
\eta_{1} \\
\eta_{2} \\
\vdots \\
\eta_{n}
\end{array}\right]
$$

Ayrıca risk faktörlerinin getiri değişimleri, günlük kapanış fiyatları dikkate alınarak geometrik getiri oranı ile hesaplanmıştır. Geometrik getiri oranı (5) numaralı formülle hesaplanmaktadır (Özden, 2007). 
$R_{t g}=\ln \left(\frac{P_{t}}{P_{t-1}}\right)$

$R_{t g}:$ t zamanındaki geometrik getiri oranı

$P_{t} \quad$ : Risk faktörünün $t$ zamanındaki değeri

$P_{t-1}$ : Risk faktörünün $t-1$ zamanındaki değeri

Riske maruz değeri belirlemek amacıyla kullanılan Monte Carlo simülasyon yönteminde aşağıdaki aşamalar uygulanmaktadır (Bolgün ve Akçay, 2005; Aktan, 2007; Koldere ve Akduğan, 2012; Avşarlıgil ve ark., 2015):

- RMD'si hesaplanacak portföyün belirlenmesi,

- Risk faktörlerinin belirlenmesi ve bunlara ilişkin tarihsel verilerin elde edilmesi,

- Portföyün risk faktörlerinin getiri değişimlerinin hesaplanması,

- Getiri değişimlerinin dağılımının hangi istatistiksel dağılıma uyduğunun tespit edilmesi,

- Risk faktörlerinin korelasyon katsayıları ve varyans/kovaryans matrislerinin hesaplanmas1,

- Belirlenen dağılıma uygun rassal sayı üretilmesi,

- Kovaryans matrisinden Cholesky \& Singular Value Decomposition matrisinin üretilmesi,

- Cholesky \& Singular Value Decomposition matrisinin tranzpozesi ile belirlenen dağılıma uygun olarak rassal üretilmiş fiyat serileri matrisinin çarpılması ile geçmişteki risk faktörleri arasındaki ilişkinin yeni üretilen fiyat serilerine yansıtılması,

- Bu fiyat serilerinin portföye uygulanması,

- İlgili güven düzeyinde RMD rakamının hesaplanması.

Çalışmada riske maruz değerin hesaplanmasında her hisse senedi için 10000 sayı üretilmiş ve bu üretilen sayılar Cholesky ayrışım matrisi transpozu ile çarpılarak Monte Carlo simülasyon değerleri elde edilmiştir.

\section{BULGULAR VE TARTIŞMA}

Hisse senetlerinin getirilerine ilişkin betimleyici istatistikler Çizelge 1'de sunulmuştur. Her biri 498 günlük kapanış fiyatlarından oluşan hisse senetleri arasında en düşük standart sapmaya sahip hisse senedi 0.03898875 ile YAPRK iken, en yüksek standart sapmaya sahip hisse senedi ise 0.05844668 ile IZTAR'dır. Bununla birlikte ortalama getirisi en düşük hisse senedi 0.00047292 ile TACTR'dir. Bu bulgular IZTAR'ın ilgili dönemde en riskli hisse senedi olduğunu göstermektedir.

Çizelge 1. Hisse senetlerinin getirilerine ilişkin betimleyici istatistikler

\begin{tabular}{lrrr}
\hline Betimleyici İstatistikler & YAPRK & TACTR & IZTAR \\
\hline Gözlem & 498 & 498 & 498 \\
Standart Sapma & 0.03898875 & 0.04964913 & 0.05844668 \\
Varyans & 0.00152012 & 0.00246504 & 0.00341601 \\
Basıklık & 8.053 & 6.769 & 3.565 \\
Çarpiklık & 0.521 & 0.228 & 0.436 \\
Ortalama & 0.00187641 & 0.00047292 & 0.00168427 \\
Minimum & -0.19306610 & -0.22270582 & -0.22314355 \\
Maksimum & 0.18121719 & 0.18232156 & 0.18232156 \\
\hline
\end{tabular}

Şekil 1'de YAPRK hisse senedinin getirisinde özellikle Mart aylarında önemli değişimler olduğu ve oynaklığın arttığ 1 görülmektedir. 
Şekil 2 değerlendirildiğinde TACTR hisse senedi getirisinde özellikle Aralık 2018 - Ocak 2019 ve Nisan-Mayıs 2019 tarihlerinde oynaklığın arttığı görülmektedir.

Şekil 3'de ise IZTAR hisse senedinin getirisinde özellikle 2018 yılı Kasım ayında oluşan yüksek oynaklık düzeyinin 2019 yılı Nisan ayında yeniden önemli bir artış gösterdiği görülmektedir.

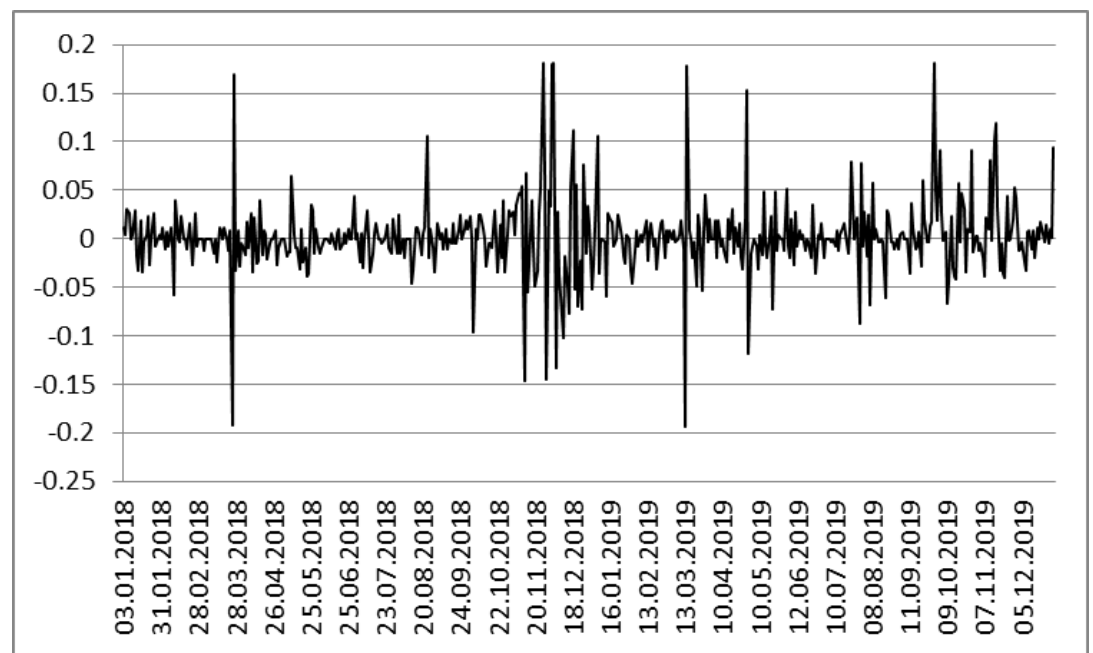

Şekil 1. YAPRK hisse senedi getirisine ilişkin zaman serisi

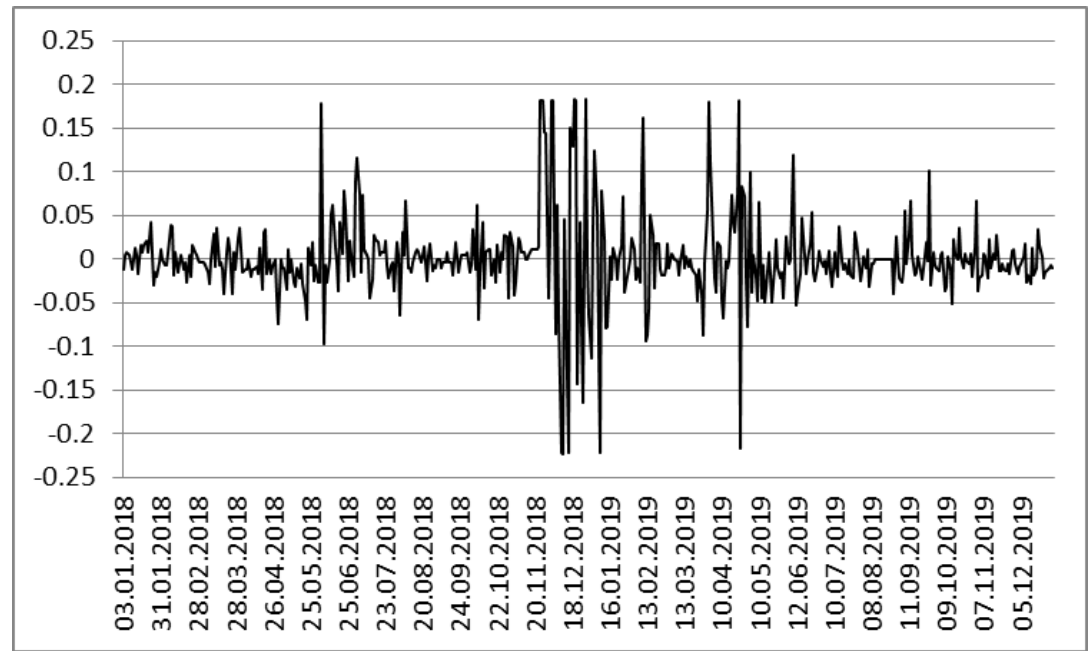

Şekil 2. TACTR hisse senedi getirisine ilişkin zaman serisi

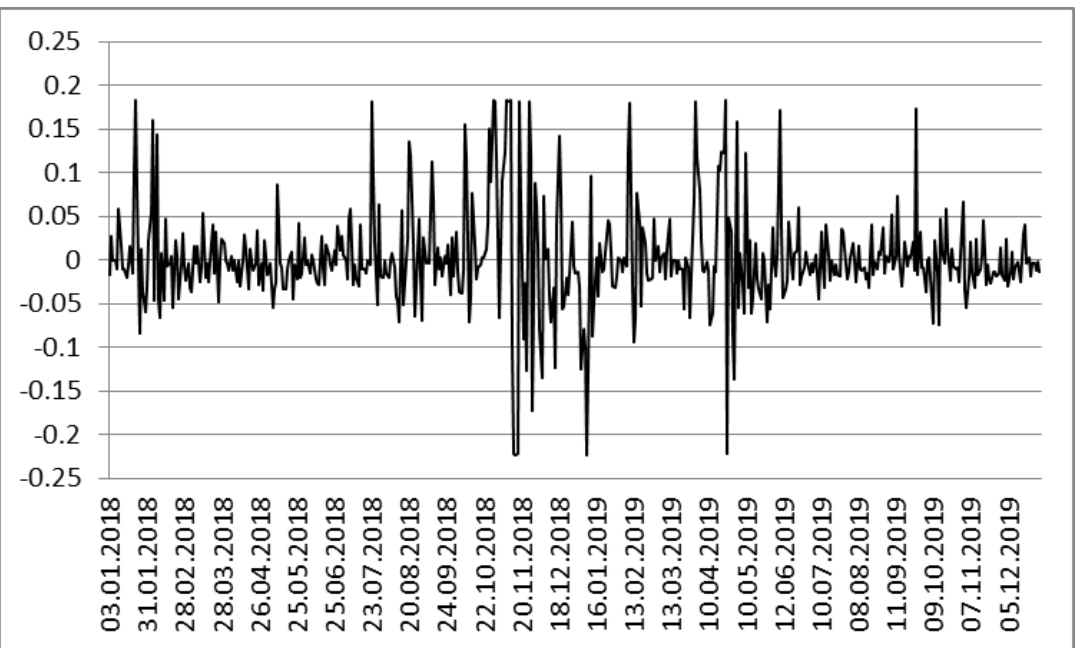

Şekil 3. IZTAR hisse senedi getirisine ilişkin zaman serisi 
Hisse senetlerinin getirilerine ilişkin korelasyon matrisi incelendiğinde getirilerin korelasyon değerlerinin pozitif yönlü olduğu saptanmıştır. Buna göre IZTAR ve TACTR getirileri arasında pozitif yönlü zayıf ilişki (0.396098) mevcut iken, IZTAR ve YAPRK getirileri arasında pozitif yönlü çok zayıf ilişki (0.170198) bulunmaktadır (Çizelge 2).

Çizelge 2. Hisse senetlerinin getirilerine ilişkin korelasyon matrisi

\begin{tabular}{lrrr}
\hline & \multicolumn{1}{c}{ YAPRK } & \multicolumn{1}{c}{ TACTR } & IZTAR \\
\hline YAPRK & 1 & & \\
TACTR & 0.262106 & 1 & \\
IZTAR & 0.170198 & 0.396098 & 1 \\
\hline
\end{tabular}

Hisse senedi getirilerine ilişkin varyans kovaryans matrisi Çizelge 3'de verilmiştir. Buna göre matrisin köşegen (diyagon) değerleri IZTAR hissesine ait oynaklık düzeyinin TACTR ve YAPRK hisse senetlerinin oynaklık düzeyinden fazla olduğunu göstermektedir. Ayrıca bu IZTAR ve TACTR hiss senetleri arasındaki birlikte hareket etme eğilimi (0.001147), IZTAR ve YAPRK arasındaki eğilimden (0.000387) daha yüksektir.

Çizelge 3. Hisse senedi getirilerine ilişkin varyans kovaryans matrisi

\begin{tabular}{lccr}
\hline & YAPRK & TACTR & IZTAR \\
\hline YAPRK & 0.001517 & 0.000506 & 0.000387 \\
TACTR & 0.000506 & 0.002460 & 0.001147 \\
IZTAR & 0.000387 & 0.001147 & 0.003409 \\
\hline
\end{tabular}

Çizelge 4'te Cholesky ayrışım matrisi ve Çizelge 5'te bu matrisin transpozu verilmiştir.

Çizelge 4. Cholesky ayrışım matrisi

\begin{tabular}{lrrr}
\hline & YAPRK & TACTR & IZTAR \\
\hline YAPRK & 0.00151700 & 0.00050600 & 0.00038700 \\
TACTR & 0.00050600 & 0.00246000 & 0.00114700 \\
IZTAR & 0.00038700 & 0.00114700 & 0.00340900 \\
\hline
\end{tabular}

Çizelge 5. Cholesky ayrışım matrisi transpozu

\begin{tabular}{lrrr}
\hline & YAPRK & TACTR & IZTAR \\
\hline YAPRK & 0.00000271 & 0.00000246 & 0.00000249 \\
TACTR & 0.00000246 & 0.00000762 & 0.00000693 \\
IZTAR & 0.00000249 & 0.00000693 & 0.00001309 \\
\hline
\end{tabular}

Bankacılık Düzenleme ve Denetleme Kurumu (BDDK) tarafından bankalara güven düzeyinin \% 99 olarak kullanılma zorunluluğu getirilmiştir. Güven düzeyinin yükselmesi hesaplanan riske maruz değeri de artıracaktır. Ayrıca BDDK yönetmeliğine göre bankaların elde tutma süresini 10 gün olarak belirleme zorunluluğu bulunmaktadır (Demireli ve Taner, 2009).

Çalışmada \% 95 ve \% 99 güven aralıklarında IZTAR, TACTR ve YAPRK hisse senetlerinden eşit ağırlıklı olarak oluşturulmuş $30000.00 \mathrm{TL}$ değerindeki varsayımsal bir portföyün riske maruz değerleri hesaplanmıştır. Buna göre \% 95 güven aralığında 1 günlük riske maruz değer portföy toplam değerinin \% 7.70'i iken; bu oran portföyü 10 gün elde tutma sonucunda \% 24.36'ya yükselmektedir. 
Güven aralığının \% 99 olarak belirlendiği durumda ise bu oranlar 1 günlük ve 10 günlük için sırasıyla \% 10.94 ve \% 34.61'dir (Çizelge 6). Aktan (2007) tarafindan MB Döviz Alış kurlarından oluşan veri seti ile yapılan çalışmada 10 günlük elde tutma süresine göre riske maruz değer oranlarının \% 95 ve \% 99 güven düzeylerine göre sırasıyla \% 13.66 ve \% 19.33 olduğu tespit edilmiştir. İMKB30 endeksi ve devlet iç borçlanma senetleri portföylerine ilişkin riske maruz değerlerinin hesaplandığı başka bir çalışmada \% 95 güven düzeyinde, 1 günlük ve 10 günlük elde tutma süresinde riske maruz değer oranı sirasıyla \% 9.02 ve \% 28.52 iken; bu oranların \% 99 güven düzeyinde sirasiyla \% 12.82 ve \% 40.55 olduğu saptanmıştır (Taş ve İltüzer, 2008). Euro, Altın ve ABD Doları'na ait verilerle eşit ağırlıkta oluşturulan portföyün riske maruz değer oranı ise \%99 güven düzeyi ve 1 günlük elde tutma süresine göre \% 1.68 olarak hesaplanmıştır (Demireli ve Taner, 2009). Yıldırım ve Çolakyan (2014) ise BİST100 endeksi, BİST30 endeksi, Dolar, Euro ve Pound verilerinden oluşturdukları bir portföy için \% 99 güven düzeyinde 1 günlük riske maruz değer oranını \% 1.90 olarak hesaplamışlardır. Banka endeksinde yer alan beş hisse senedinden eşit ağırlıkta oluşturulan bir portföyün riske maruz değerinin hesaplandığı başka bir çalışmada ise portföyün riske maruz değer oranı \% 99 güven düzeyi ve 10 günlük elde tutma süresine göre 2015, 2016 ve 2017 yılları için sırasıyla \% 18.80, \% 16.37 ve \% 11.99 olarak hesaplanmıştır (Bayram ve Kısava, 2019). Bu çalışmalar bütünsel olarak değerlendirildiğinde farklı dönemlerde yapılan çalışmalarda yatırım araçlarının riske maruz değerlerinin farklılık gösterdiği görülmektedir. Bu çalışmada elde edilen sonuçlar önceki çalışmaların sonuçlarıyla karşılaştırıldığında tarım sektörü hisse senetlerinden oluşan bir portföyde riske maruz değer oranının genellikle daha fazla olduğu görülmektedir. $\mathrm{Bu}$ nedenle tarım sektörü hisse senetlerinden oluşan portföy riskinin daha yüksek olduğu söylenebilir.

Çizelge 6. Monte Carlo simülasyon yöntemine göre portföyün riske maruz değerleri

\begin{tabular}{llrr}
\hline \multicolumn{3}{c}{ Porftöy Toplam Değeri (TL) } \\
30000.00 \\
\hline Elde Tutma Süresi & Değişkenler & \% 95 Güven Aralı̆̆ı & \% 99 Güven Aralı̆̆ı \\
\hline \multirow{2}{*}{1 Gün } & Riske Maruz Değer (TL) & 2311.02 & 3283.33 \\
& Riske Maruz Değer Oranı & $\% 7.70$ & $\% 10.94$ \\
& & & \\
\multirow{2}{*}{10 Gün } & Riske Maruz Değer (TL) & 7308.08 & 10382.82 \\
& Riske Maruz Değer Oranı & $\% 24.36$ & $\% 34.61$ \\
\hline
\end{tabular}

\section{SONUÇ}

Finansal varlıklarda görülen fiyat dalgalanmaları sermaye piyasasında belirsizliğe neden olmakta ve bu belirsizlik yatırımcılar açısından önemli bir risk oluşturmaktadır. Bu nedenle yatırımcılar açısından risk yönetimi ve buna ilişkin araçların kullanımı önem arz etmektedir. $\mathrm{Bu}$ araştırmada risk yönetiminde yararlanılan yöntemlerden biri olan Monte Carlo simülasyonu tarım sektörü hisse senetlerinden oluşan bir portföyün riske maruz değerini hesaplamak için kullanılmıştır.

Elde edilen sonuçlar tarım sektörü hisse senetlerinden (IZTAR, TACTR, YAPRK) oluşan bir portföyü 10 gün elde tutma süresinde $\% 95$ ve \% 99 güven düzeylerinde sırasıyla $\% 24.36$ ve $\% 34.61$ oranında risk bulunduğunu göstermektedir. Aynı yöntemle hesaplanmış diğer çalışmalarla karşılaştırıldığında 10 gün elde tutma süresinde bu risk oranının döviz (\% 95 ve \% 99 güven düzeylerinde sirasıyla \% 13.66 ve $\%$ 19.33), bankacılık hisse senetleri (\% 99 güven düzeyinde $\%$ 18.80) ve devlet iç borçlanma senetlerinden (\% 95 ve \% 99 güven düzeylerinde sirasılyla \% 6.35 ve \% 
9.11) oluşan portföylerin risk düzeyinden daha fazla olduğu belirlenmiştir. Finansal varlıkların yer aldığı sermaye piyasasında bu varlıkların fiyatı ulusal ve küresel ölçekte meydana gelen gelişmeler, şirket performansı, izlenen para politikaları ve doğal afetler gibi faktörlerden etkilenmektedir. Ancak fiyatı belirleyen temel unsurlar bu varlıklara ilişkin arz ve taleptir. $\mathrm{Bu}$ nedenle araştırma sonucunda elde edilen yüksek risk düzeyi, fiyatı belirleyen diğer faktörlerin yanı sıra talebi oluşturan yatırımcı kararlarıyla da ilişkilendirilmelidir. Dolayısıyla bundan sonraki çalışmalarda tarım sektörü hisse senetlerinden oluşan portföy riskinin diğer portföylere göre daha yüksek olmasının nedenlerini inceleyen ve yatırımcı kararlarını belirleyen faktörleri de dikkate alan araştırmaların yapılması önerilmektedir. Bununla birlikte tarım sektörü hisse senedi fiyatlarında gözlenen bu dalgalanmalar ilgili dönemlerde tarım sektörünü etkileyebilecek petrol fiyatları, tarım ürünü fiyatları veya döviz kurundaki değişimlerle ilişkili olabilir. Bu değişimlerin yatırımcı kararlarında etkili olabileceği düşünülmekle birlikte bunlarla ilgili sonuçlara ulaşabilmek için ilgili değişkenlerle hisse senedi fiyatlarının nedensellik ilişkisi incelenmelidir.

\section{KAYNAKLAR}

Akan B, Oktay A, Tüzün T, 2003. Parametrik Riske Maruz Değer Yöntemi ve Türkiye Uygulaması. Bankac1lar Dergisi, 14(45): 29-39.

Aktan B, 2007. Ticarî Bankalarda Risk Yönetimi ve Monte Carlo Var Simülasyon Yöntemiyle Portföy Riskinin Hesaplanmas1. Adnan Menderes Üniversitesi Sosyal Bilimler Enstitüsü, Doktora Tezi.

Anonim, 2020. Kamuyu Aydınlatma Platformu, Sektörler, https://www.kap.org.tr/tr/Sektorler (Erişim Tarihi: 07.04.2020).

Avşarlıgil N, 2020. Bulanık Programlamayla Portföy Optimizasyonu Üzerine Bir Uygulama. Pamukkale Üniversitesi Sosyal Bilimler Enstitüsü Dergisi, Sayı 38: 197-209.

Avşarlıgil N, Demir Y, Doğru E, 2015. Riske Maruz Değer Ölçüm Yöntemleri Aracılığıyla BIST’te İşlem Gören Spor Kulüpleri Üzerine Bir Uygulama. Eskişehir Osmangazi Üniversitesi Sosyal Bilimler Dergisi, 16(1): 81-107.

Bayram O, Kısava ZS, 2019. Riske Maruz Değer Analizi Üzerine Bir Uygulama: Türkiye'den Bulgular. Avrasya Sosyal ve Ekonomi Araştırmaları Dergisi, 6(1): 269-279.

Bolgün E, Akçay B, 2005. Risk Yönetimi, 2. Basım, Scala Yayıncılık, İstanbul.

Demireli E, Taner B, 2009. Risk Yönetiminde Riske Maruz Değer Yöntemleri ve Bir Uygulama. Süleyman Demirel Üniversitesi İktisadi ve İdari Bilimler Fakültesi Dergisi, 14(3): 127-148.

Embrechts P, Puccetti G, 2010. Risk Aggregation. In: Copula Theory and Its Applications. (Eds: P. Jaworski, F. Durante, W. Hardle, and T. Rychlik), Springer-Verlag Berlin Heidelberg, pp. 111126.

Eser Ö, 2010. Piyasa Riski Ölçümü Olarak Riske Maruz Değer ve Hisse Senedi Portföyleri İçin Bir Uygulama, Kadir Has Üniversitesi Sosyal Bilimler Enstitüsü, Yüksek Lisans Tezi.

Jorion P, 2007. Value at Risk: The New Benchmark for Managing Financial Risk. (Third edition), McGraw-Hill, USA, 602 pp.

Kavrar Ö, Yılmaz B, 2019. Riske Maruz Değer Yöntemiyle Portföy Riskinin Belirlenmesi. Marmara Üniversitesi Öneri Dergisi, 14(52): 486-508.

Koldere Akın Y, Akduğan U, 2012. Finansal Piyasalarda Risklerin Belirlenmesinde Riske Maruz Değer Yöntemine İlişkin Bir Uygulama. Trakya Üniversitesi Sosyal Bilimler Dergisi, 14(1): 225-236.

Korkmaz T, Pekkaya M, 2012. Excel Uygulamalı Finans Matematiği. 3. Baskı, Ekin Basım Yayın, Bursa. 
Küçük F, 2010. Kredi Riski Yönetiminde Monte Carlo Simülasyon Yöntemi. Yıldız Teknik Üniversitesi Fen Bilimleri Enstitüsü, Yüksek Lisans Tezi.

Özden ÜH, 2007. Riske Maruz Değer (RMD) Hesaplama Yöntemleri: İMKB Üzerine Uygulama. Öneri, 7(28): 279-285.

Şener C, 2018. Monte Carlo Simülasyonu ile Hisse Senedi Fiyat Tahminleri. İstanbul Aydın Üniversitesi Sosyal Bilimler Enstitüsü, İşletme Anabilim Dalı Yüksek Lisans Tezi, 159 sy.

Taş O, İltüzer Z, 2008. Monte Carlo Simulasyon Yöntemi ile Riske Maruz Değerin İMKB 30 Endeksi ve DİBS Portföyü Üzerinde Bir Uygulaması. Dokuz Eylül Üniversitesi İktisadi ve İdari Bilimler Fakültesi Dergisi, 23(1): 67-87.

Uçkun N, Kandemir S, 2008. Risk Ölçümünde Riske Maruz Değer Metodolojisi ve İMKB'de Bir Uygulama. Muhasebe ve Finansman Dergisi, Sayı 38: 123-131.

Ural M, 2009. Riske Maruz Değer Hesaplamasında Alternatif Yaklaşımlar. BDDK Bankacılık ve Finansal Piyasalar, 3(2): 63-86.

Usta Ö, 2008. İşletme Finansı ve Finansal Yönetim. Detay Yayıncılık, Ankara.

Usta Ö, Demireli, E., 2010. Risk Bileşenleri Analizi: İMKB'de Bir Uygulama. Zonguldak Karaelmas Üniversitesi Sosyal Bilimler Dergisi, 6(12): 25-36.

Yıldırım H, Çolakyan A, 2014. Finansal Yatırım Araçlarında Riske Maruz Değer Uygulaması. Dokuz Eylül Üniversitesi İktisadi ve İdari Bilimler Fakültesi Dergisi, 29(1): 1-24.

Yıldırım H, Kantar, G, 2018. Sistematik ve Sistematik Olmayan Risk Politikası: BIST100'de İşlem Gören Seçilmiş Şirketlere Ait Hisse Senetlerinden Oluşturulan Portföy Üzerine Bir Uygulama. The Second International Conference on Current Trends in the Middle East 2018, 5-9 November, Tekirdağ/Turkey.

Zhu H, Liu T, Zhou E, 2020. Risk Quantification in Stochastic Simulation under Input Uncertainty. ACM Transactions on Modeling and Computer Simulation, 30(1): 1-24. 